\title{
Remembering Kwadwo Donkoh and Stan Plange: Ghanaian Dance Band Highlife Music Composer and Arranger
}

\author{
Mark Millas Coffie \\ Edwin E. A. Ferguson \\ Stephen Ayesu Nyanteh \\ Department of Music Education \\ University of Education, Winneba \\ Ghana
}

\begin{abstract}
The purpose of this study is to reflect on the life, music and contributions of Kwadwo Donkoh and Stan Plange to the development of Ghanaian dance band highlife music. It also examines the compositional devices and arranging techniques employed in one of their popular highlife songs, Wobe kume (you will kill me) as a contribution to music theory. Employing document review and interview for data collection, the paper reveals that both Kwadwo Donkoh and Stan Plange composed and arranged for several bands. A formal analysis of the song, Wobe kume also reveals manipulation of sequential interlocking patterns, repetitions, variations and transposition in the vocal melody, while the arrangement employs a technique of 'double theme brass and vocal alternation'. The study concludes that the song is a contribution to music theory; and therefore, recommends the use of Ghanaian dance band highlife songs for the teaching of composition and 'big band' arranging techniques, and musical form and analysis in music institutions.
\end{abstract}

Keywords: arranger; composer; dance band; highlife; songwriter; wobe kume

\section{Introduction}

Kwadwo Donkoh and Stan Plange, arguably two of Ghana's prolific dance band highlife composers and arrangers chalked successes with several bands in Ghana and Nigeria; most notably are Stargazers, Ogyatanaa, Broadway and Uhuru Dance Bands from Ghana, and E.C. Arinze's Band, Nigeria Broadcasting Orchestra and Ambassador's Down Beats Band from Nigeria. Interestingly, Kwadwo and Stan have been in the business of one composing the vocal melody and the other arranging for quite long. This is evident in highlife classics such as Skin pain, Time for highlife, Wobe tumi no, Biribi just to mention a few of the many examples, where Kwadwo composed the vocal melody and Stan did the arrangement. It is quite surprising that they are among the least celebrated highlife greats in Ghanaian popular music parlance as compared to their contemporaries such as Ebo Taylor, Teddy Osei, C. K. Mann among others.Wobe kume (you will kill me) is arguably one of Ghana's classic highlife songs composed by Kwadwo Donkoh and arranged by Stan Plange in the dance band highlife style. Sadly, these two Ghanaian dance band highlife greats have passed on. Even though Ghanaians could relate with the song, it appears their popularity, musicality and achievements live in the memory of their contemporaries, a few music pundits and those who encountered them while they were alive. It is the purpose of this study to reflect on the life, music and contributions of Kwadwo Donkoh and Stan Plange to the development of Ghanaian dance band highlife music, and also examines the compositional devices and arranging techniques employed in one of their popular highlife songs, Wobe kume as a contribution to music theory.

\section{Literature Review}

Dance band highlife is one of the distinct forms of Ghanaian highlife music, which evolved out of the pre-World War dance orchestras of the 1900s (Collins, 1994, 2004). It is a synthesis of indigenous Ghanaian music, Western classical music, Afro-Cuban music and jazz. The dance band highlife music was one of the dominant music forms in the musical landscape of Ghana between the late 1940s to the late 1970s. The popularity of dance bands such as Tempos, Black Beats, Stargazers, Broadway, Ramblers, Uhuru among others in and outside Ghana during the above-mentioned period cannot be overemphasised. (Coffie, 2012) posits that no style of highlife has projected Ghana so well on the world music map like the dance band style, which also gives credence to the above statement. Dance band highlife composers and arrangers superimpose Western idiomatic structure and instruments over African thematic sources as observed by (Coffie, 2018). 
In her seminal work on Popular Music of West Africa (Smith, 1962) contended that the future of popular music in West Africa depends largely on the quality of dance band and guitar band musicians. Smith further stated that these musicians, besides their performing role, also compose and teach a large part of the instrumental music. Hence, their professional development will enhance the playing, composition and teaching of the music in subsequent development. Despite the multiculturalism of the dance band highlife style, its study in Ghanaian academic institutions is still at the infantile stage. Studies on highlife tend to focus on the social history and biography of the musicians. (Coplan, 1978), (Aduonum, 1983), (Collins, 1985, 1986, 2016, 2018), (Bender, 1991), (Ampomah, 2013) among others exemplify the above statement. That notwithstanding, recent studies such as (Kudonu, 2012), (Aidoo, 2014), (Amuah, Sunu Doe, Fiagbedzi, \& Amenyo, 2014) and (Marfo, 2016) have attempted to investigate highlife songs. However, they mostly focus on the vocal melody, thereby relegating the instrumental components that have shaped the entire song. It is on this background that we reflect on the life, music and contributions of Kwadwo Donkoh and Stan Plange to the development of Ghanaian dance band highlife music, and also examines the compositional devices and arranging techniques employed in one of their popular highlife songs, Wobe kume (you will kill me) as a contribution to music theory.

\section{Methodology}

This study employed a case study research design and formal musical analysis. This study is an extract from a bigger work we are undertaking on Ghanaian Big Band Highlife Composers \& Arrangers as a resource material for the Study of Ghanaian Popular Musicians. Data for this paper was collected between 2011 and 2012. Securing a fundament for analysis, an oral interview was conducted with Kwadwo Donkoh and Stan Plange to get an insight into their life, music and contributions to the development of Ghanaian dance band highlife music. Wobe kume was purposely selected for analysis not only because of its classicism but also it is the most popular song among their solo and collaborated works. The song was subjected to critical listening and transcribed into a musical score. The score became the starting point for a thorough analysis to get an insight into the melody fluency, instrumental structures and arranging style in the context of dance band highlife music. In the process of reflection, we also discuss the textual meaning of the song. In this study, we refer a songwriter to the one who writes the lyrics (vocal melody and text), and arranger to the one who orchestrates the instrumental sections in relation to the voice. Hence, the term songwriter is used interchangeably with the term composer throughout this paper. Similarly, the term dance band is also used interchangeably with big band.

\section{Results and Discussion}

\subsection{The Early Life and Education of Kwadwo Donkoh}

Kwadwo Donkoh christened Opoku Agyeman Kwadwo Whittle Donkoh, was born to Charles and Agnes Donkoh on 12th November 1934 at Wenchi in the Brong Ahafo Region of Ghana. He had his elementary education in Wenchi and proceeded to Mfantsipim School in Cape Coast for his School Certificate and High School Certificate from 1950-1955. He then proceeded to the University of Ghana, Legon in 1956 and graduated with a Bachelor of Arts degree in History in 1959. During his days at Legon, he was made the entertainment secretary of Third Hall. ${ }^{1}$ He used to invite the Black Beats Band for the hall's entertainment shows due to the rapport he had with Jerry Hansen, a big band highlife great, whom he later composed a song for his band, Ramblers (Coffie, 2012). Before his compositions, his father, who was not musically inclined, bought him a harmonium in the 1940s but, due to lack of tutorship, he could not learn to an appreciable level. Kwadwo Donkoh also became interested in highlife music through the shows of guitar band musicians such as Kobina Onyina, E. K. Nyame, Happy Stars, Yamoah and many others. These shows were organised by a society in the university called African Music Society, which involved academicians like J. H. Nketia, Atta Annan Mensah, Robert Sprigge and E. F. Collins in the 1950s. ${ }^{2}$ Due to the class distinctions between the guitar bands and dance bands in the 1950s, students in the university at that time preferred to invite dance bands for shows on campus rather than the guitar bands. This is probably because the students perceived the guitar bands as low life and the dance bands high life. The African Music Society, however, started inviting the guitar bands to perform at the university. These guitar band musicians through their shows on campus later became a great influence on Kwadwo Donkoh (Collins, 2016).

\subsection{Kwadwo Donkoh's Music Career}

Kwadwo Donkoh's musical ability is rooted in song writing, unlike his contemporaries like Ebo Taylor, Stan Plange and Ray Ellis who were also fantastic instrumentalists beside their compositional and arranging skills.

\footnotetext{
1 The Third hall is what is now referred to as the Commonwealth hall

2 Personal communication with Collins on 21 st July 2012
} 
He had his training in music purely through imitation, which is copying what the highlife and jazz greats of the time were doing, and was self-taught through practical experience. Kwadwo Donkoh joined the diplomatic service after his university education; however, his love for music made him compose for dance bands alongside his diplomatic duties. In 1961, he composed Time for Highlife for E.C. Arinze's band in Lagos when he was on official duty as the first secretary of Ghana High Commission in Nigeria. Kwadwo was transferred to London in 1964, where he met some Ghanaian musicians and composed for them. ${ }^{3}$ Kwadwo Donkoh was later transferred to Brussels, Belgium in an attempt to stop him from pursuing his music career. According to him, "one of my subordinates reported me to my superiors about my growing interest in music. For him, I concentrated on music more than my core diplomatic duties." In 1969, Kwadwo Donkoh resigned from diplomatic service to concentrate on his music after nine years of service to his nation. He formed his first band, the Houghas; after one businessman he had met and helped in Brussels purchased musical instruments for him. The band was later dissolved, and he went on to form his second band, Ogyatanaa. Kwadwo formed this band purposely to experiment and perform his compositions. He also formed another group, the Abokyi Parts, in honour of Kojo Abokyi, a great highlife singer. Kwadwo did a groundbreaking job when he discovered and produced the first two albums ${ }^{5}$ of the Ga group, Wulomei in 1975. Some of the prominent groups and artistes he produced include Dzadzeloi, Uhuru Dance Band, the Abokyi Parts, Ogyatanaa, Ray Ellis, E.K. Nyame and Kobina Okai.

\subsection{Kwadwo Donkoh'sLater Years and Wishes}

At the time of this interview, 77-year old Kwadwo Donkoh was still composing and also planning with Essiebons Records to re-produce some of his old songs. He also had plans to record a highlife album, which he referred to as typical highlife. In 2000, he proposed the idea of a national songbook for schools to the Ministry of Education but this never came to fruition. In 2006, he secured a grant from the Danish Embassy and Ghana Cultural Fund to record and transcribe over hundred highlife melodies. The purpose of the project was to preserve classic highlife songs and distribute them to schools. According to him, musicians such as E.K. Nyame, Kobina Onyina, Kakaiku and Kobina Okai had a great influence on him locally, whereas Louis Armstrong, Ray Charles, Glen Miller, Nat King Cole, Aretha Franklin, Quincy Jones and to some extent Stevie Wonder were a great influence on him internationally. Sadly, Kwadwo Donkoh died on 5th May 2016. Kwadwo Donkoh's significant contribution to the development of dance band highlife is his songwriting prowess, through which he wrote songs for both the pioneers and his contemporaries of 'big band' style of highlife music. Some of his compositions include Go Slow, Biribi, Honey Honey, Skin Pain, Wobe kume, ebcycyie, Wobetumi no, Nmsbrowa, Agya Nyame, Yerefrefre, and Aware so.

\subsection{The Early Life and Education of Stan Plange}

Stan Plange was born on 29th April 1937 in Accra to Robert Plange and Mercy Kwaley Quartey. His father, a trumpeter, used to play with the Accra Orchestra formed. This, however, suggests the beginning of big band music influence on him. Stan started his elementary education at the Government Boys School in Accra and proceeded to Adisadel College at Cape Coast in 1952. After secondary school, Stan worked at the Bank of Ghana as a junior clerk for a short period.

\subsection{Stan Plange's Music Career}

According to Stan, he used to be a member of the school choir during his elementary school days; however, that was not the reason for his interest in music. He grew up in a vicinity near the Kit-Kat Club at Adabraka, opposite the Roger Cinema where he had the opportunity to see the Rhythm Aces Band led by Spike Anyankor, a saxophonist and other great musicians perform. Hence, he was influenced to learn to play the guitar and forced himself into the Down Beats band (Collins, 1994). Stan started his professional music career with a Nigerian band domiciled in Ghana called the Down Beats in 1957 led by Chief Bill Friday. From the Down Beats, he joined the First Comets led by Ray Ellis, a pianist. The First Comets was a second band to the Rakers, the resident band of Tip-Toe Night Club. After the Comets, he joined a series of bands, which did not last. Stan then left for Kumasi to join the Ashanti Nkramo band and later left for Stargazers band in 1958.

\subsection{Stan Plange in Nigeria}

In the latter part of 1958, Stan left the Stargazers, which was a combo band at that time to join his former band, the Down Beats by then relocated to Nigeria.

\footnotetext{
3 Some of these musicians included Teddy Osei of Osibisa fame

4 Interview with Kwadwo Donkoh in December 2011

5 The titles of the albums were Walatu Walasa and Mibschi
} 
They resided in a hotel called Ambassadors Hotel, hence the name Ambassadors Down Beats. Stan played with the Down Beats in the capacity as a guitarist, an arranger and assistant leader. While in Nigeria from 1958 to early 1962, he also played with the Nigerian Broadcasting Orchestra as a guitarist and arranger, which was his first big band. It was in the Broadcasting Orchestra, that the director, Fela Sowande, an internationally known musician, influenced him. Fela Sowande influenced his writing and arrangement for big band. Steve Rhodes, who also used to be with the Nigerian Broadcasting Orchestra, was a great influence on Stan in dance music.

\subsection{Stan Plange's Return to Ghana}

Stan at a point realised that there were better opportunities back in Ghana than Nigeria and fortunately for him, D.K. Kusi, a timber contractor was reforming the Stargazers band in Ghana, but this time in a big band form. He was, however, invited by D. K. Kusi to join the Stargazers in Kumasi around 1962. Not too long, Stan received another invitation to join the Broadway Band in Takoradi around 1964 after Ebo Taylor, a guitarist and an arranger had left. During his days at Broadway, there arose a misunderstanding between the musicians and the owner of the band, which led to the disbandment of the band. Later the musicians left and formed the Uhuru Dance Band led by Sammy Obot, a Nigerian. Stan later became the leader of the band after Sammy Obot had left for Britain. He later left the Uhuru Dance Band in 1972 to team up with Faisal Helwani, a music producer to form a record company called Obibini Records. Due to financial problems, he left for the Black Star Line Band as Music Director for two years and later left for the Ghana Broadcasting Band as Director. According to Stan Plange, his musical training was mostly by a correspondence course. He did a course at Berklee College of Music in the United States of America in 1963. He experimented with whatever he had learned through the correspondence course on the bands he played. He is mainly a self-taught musician and admits that he did not do so many compositions as compared to arrangements. He narrates; "emphasis was not put on compositions but rather arrangements because now and then people were bringing their compositions for me to streamline certain parts and arrange for big bands." ${ }^{6}$ Great musicians like Count Basie, Nat King Cole, Steve Rhodes and Fela Sowande were a great influence on him internationally; however, Ray Ellis influenced him locally. Sadly, Stan Plange died on 21st April 2015. Some of his arrangements include Nkrobs, Wobe kume, Mafamanycyie, Konkoma Medley, Lawuti, WobeTumi No, Time for Highlife, Biribi and Skin Pain. One of Stan Plange's significant contributions to the development of dance band highlife is his excellent big band arranging prowess, through which he arranged songs for all the bands he played.

\section{About the Song, Wobe kume}

This song, as mentioned earlier was composed and arranged by Kwadwo Donkoh and Stan Plange respectively and recorded by the Uhuru Dance Band on Philips Record Label in 1971. The song is about a man appreciating the beauty of a woman. He accepts the fact that the beauty of this woman could kill him. He laments on how he had searched for such a beauty for a long time and that he is now glad to have finally found one. He states that besides her beauty, it is the way she walks that moves him the most. The song is built on the text motive, wobe kume, which repeats severally in the song. Written in Twi, a Ghanaian language, the song is devoid of proverbs, which also makes it easy for the listener to readily understand the songtext. This song makes use of vocal extensions such as "a", "ee" and "oo", which is sometimes referred to as "melisma" or "non-semantic syllables" at the end of text cells and usually occurs at the beginning or ending of phrases (Webb, 2011). The composer employed these vocal extensions purposely to express emotions and also embellish the song.

\footnotetext{
${ }^{6}$ Interview with Stan Plange on 16th February 2012
} 
Table 1: Song text

\begin{tabular}{|l|l|}
\hline Songtext & Translation \\
\hline Wobe kumesds 'ee' wobe kume & You'll kill me, my love, you'll kill me \\
\hline Afedecmenyakase, wobe kume 'oo' wobe kume & I have now accepted that you'll kill me, you'll kill me \\
\hline Wobe kume onua 'ee' wobe kume & You'll kill me, my friend, you'd kill me \\
\hline Afedecmenyakasc, wobe kume 'oo' wobe kume & I have now accepted that You'll kill me, you'll kill me \\
\hline Ahuoffbefuanie 'a', walkingsbefuanie 'a' & Oh, what a beauty! Oh, what kind of walk! \\
\hline $\begin{array}{l}\text { Mena me kyerese me kyinkyin, Me kyinkyin, ma nante ma } \\
\text { bre }\end{array}$ & $\begin{array}{l}\text { I confess that I have been searching and tired of } \\
\text { walking }\end{array}$ \\
\hline Nansodabidabidabidabi, woe decmenyakascwobe kume & But I know one day I will accept that you'll kill me \\
\hline $\begin{array}{l}\text { Mena me kyerss me kyinkyin, Me kyinkyin, ma nante ma } \\
\text { bre }\end{array}$ & $\begin{array}{l}\text { I confess that I have been searching and tired of } \\
\text { walking }\end{array}$ \\
\hline Nansodabidabidabi 'oo', woe decmenyakascwobe kume & But I know one day I will accept that you'll kill me \\
\hline
\end{tabular}

\subsection{Vocal Solo}

The structural organisation of the vocal solo can be regarded as being in binary form (AB). Examination of the (A) sectionof the vocal solo reveals the use of short melodic motives, which can also be treated as question and answer. As illustrated in figure 1 below, the vocal solo begins with note repeats on the tonic and descends to the dominant before ascending to the lowered seventh note in bar 6, which is also active in the direction of the tonic.

Figure 1: Vocal melody (A1)

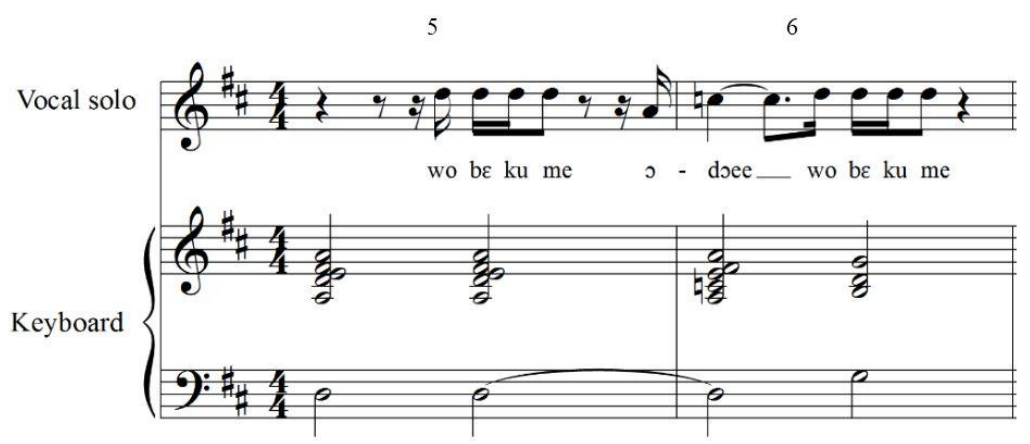

The lowered seventh note, which is approached by a leap and resolved by a step in bar 6 can be looked at as an influence of traditional vocal music practice of the Akans of Ghana. Notice that the repetition of the tonic in bar 6 does not sound conclusive because the keyboard supports the melody with chord IV, which suggests a question in bars 5-6.

Figure 2: Vocal melody (A2)

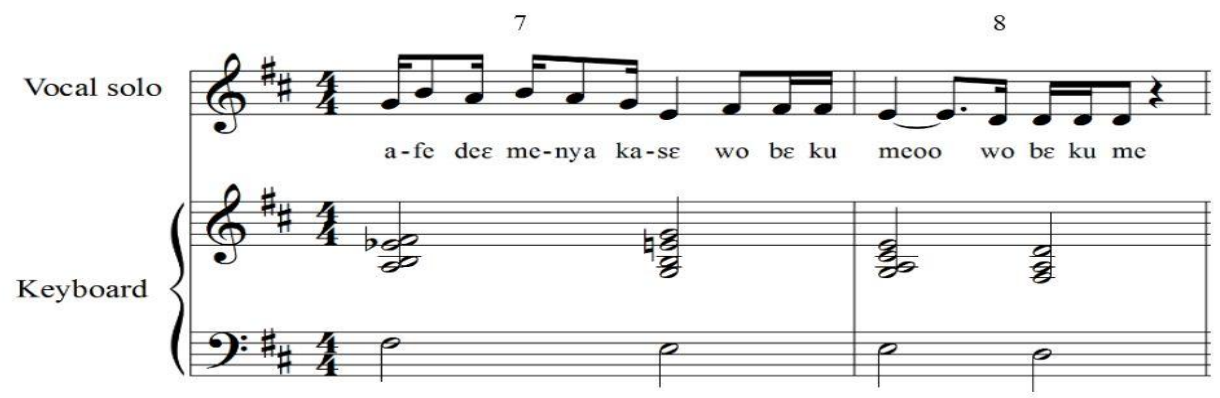

Referring to the illustration in figure 2 above, the vocal solo continues on the subdominant, interlocks by ascending third, descending and ascending seconds in the first half of bar 7 before it repeats the mediant in bar 7 last beat. Note that the resolution of the mediant to the supertonic in bar 8 , supported with chord $\mathrm{V}_{3}^{4}$ by the keyboard gives the supertonic its strong tendency to resolve to the tonic, which sounds conclusive in a perfect cadence and also suggests an answer to the earlier question in bars 5-6. To help the listener remember the basic idea of the melody and at the same time differentiate the various sections, the songwriter repeats the vocal melody in bars 5-8, but not without variation. See the illustration in figure 3 below. 
Figure 3: Vocal Melody (A1) variation

(a)

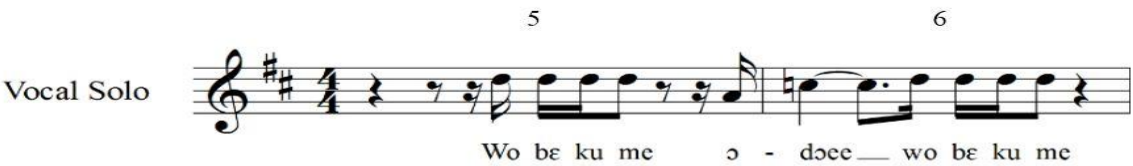

(b)

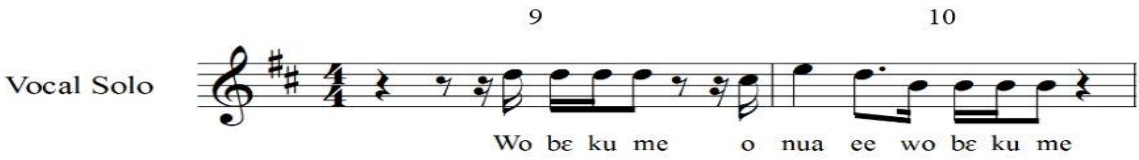

Comparing bars 5-6 to 9-10, as shown in the illustration above, it appears that the songwriter transposed the melodic idea in the last beat of bars 5-6 a minor $3^{\text {rd }}$ up in bar 9 last beat to bar 10 first beat. Notice the supertonic in bar 10 first beat, which can be treated as an appoggiatura; thereby giving the tonic a strong tendency to resolve to the submediant. The alteration of the lowered seventh note that is $(\mathbf{C}$ to $\mathbf{C \# )}$ in bar 9, however, gives an impression that the lowered seventh note in bar 6 is used for decoration. Also, comparing bars 7-8 to bars 11-12 as illustrated in figure 4 below, the songwriter varies the vocal melody slightly. Notice the resolution of the mediant to the supertonic in bars 7-8; however, in bars, 11-12, the median resolves to the leading note.

\section{Figure 4: Vocal melody (A2) variation}

(a)

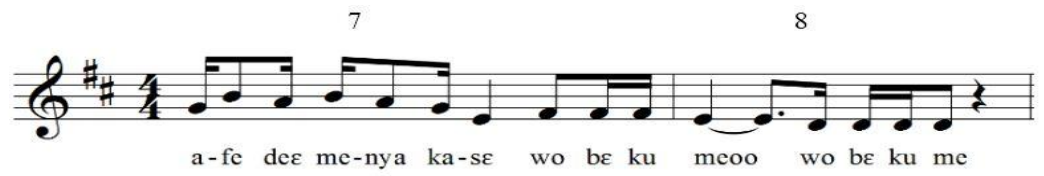

(b)

Vocal solo

wo be ku me

Vocal solo

11

12

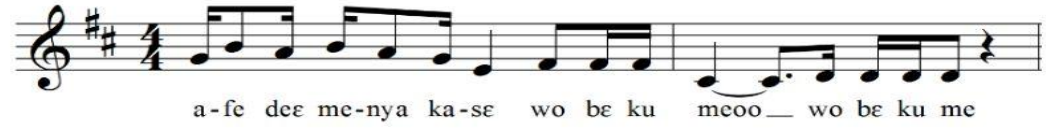

Figure 5: Vocal melody (B1)

13

14

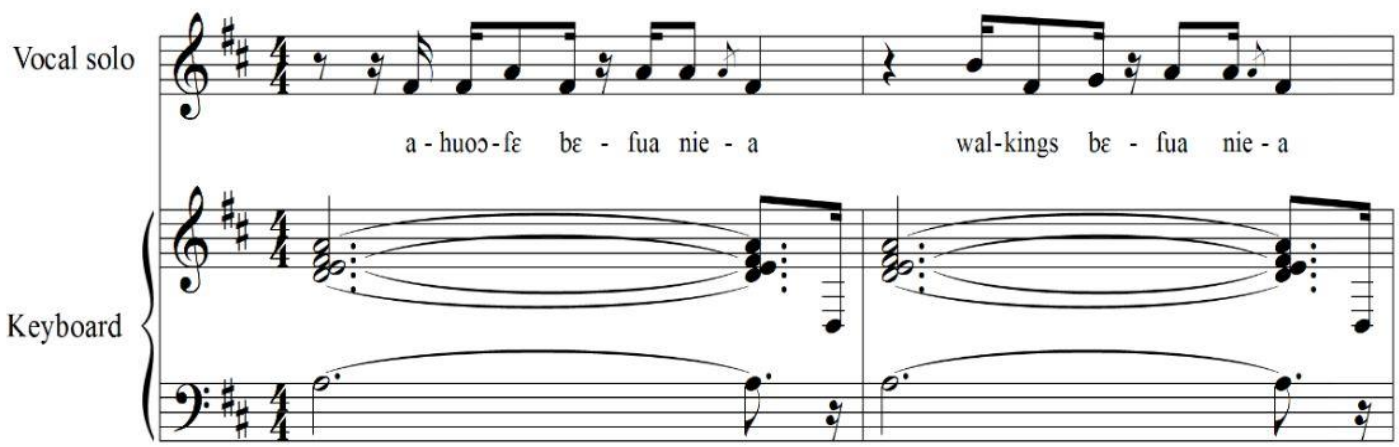

The (B) section of the vocal soloas illustrated in figure 5 above also begins with note repeats and interlocking pattern in bar 13 with a strong melodic tendency to move on, but being supported with chord I in the keyboard, the melody appears to be uncertain in bars 13-14. This impression is supported by the sudden move of the melody from F\#4 in bar 14 to $\mathbf{F \# 5}$ in bar 15. See the illustration in figure 6 below. 
Figure 6: Vocal melody (B2)

$\begin{array}{llll}15 & 16 & 17 & 18\end{array}$

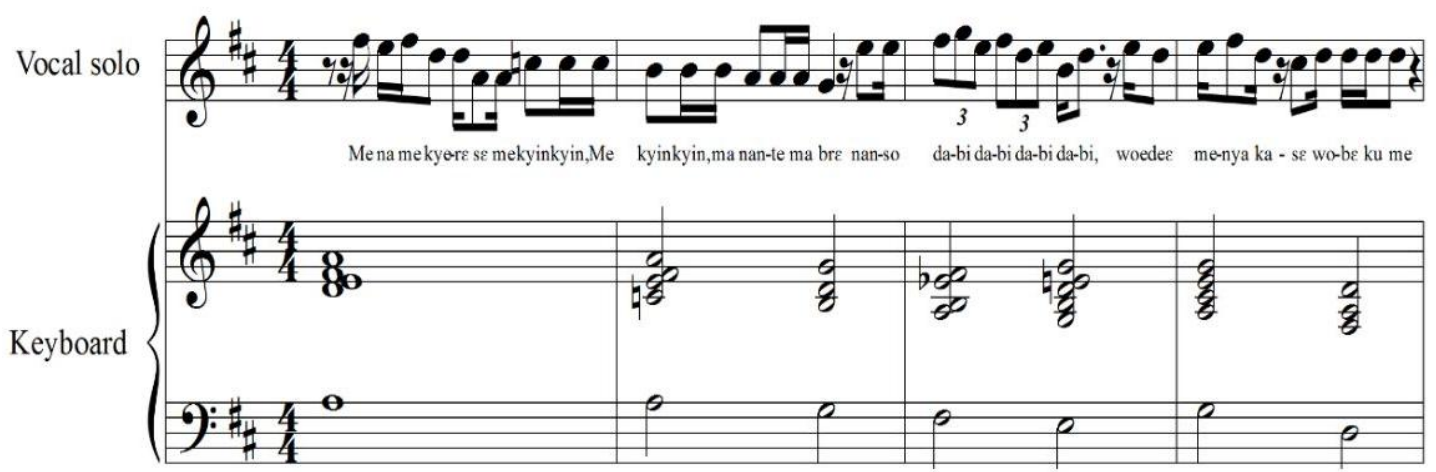

Referring to the illustration in figure 6 below, the melody in bar 15 descends to the dominant on the third beat, ascends to the lowered seventh note in bar 15 last beat, descends to the subdominant in bar 16 third beat, ascends to the supertonic in bar 16 last beat before reaching its climax in bar 17. The leading note, being approached from above by the tonic in bar 18 first beat, has its strong tendency to resolve back to the tonic in a perfect cadence. Notice that from bar 19-22 is a varied repetition of bars 15-18. For example, bar 15 and 19, and bar 17 and 21.

\section{Figure 7: Vocal melody (B2) variation}

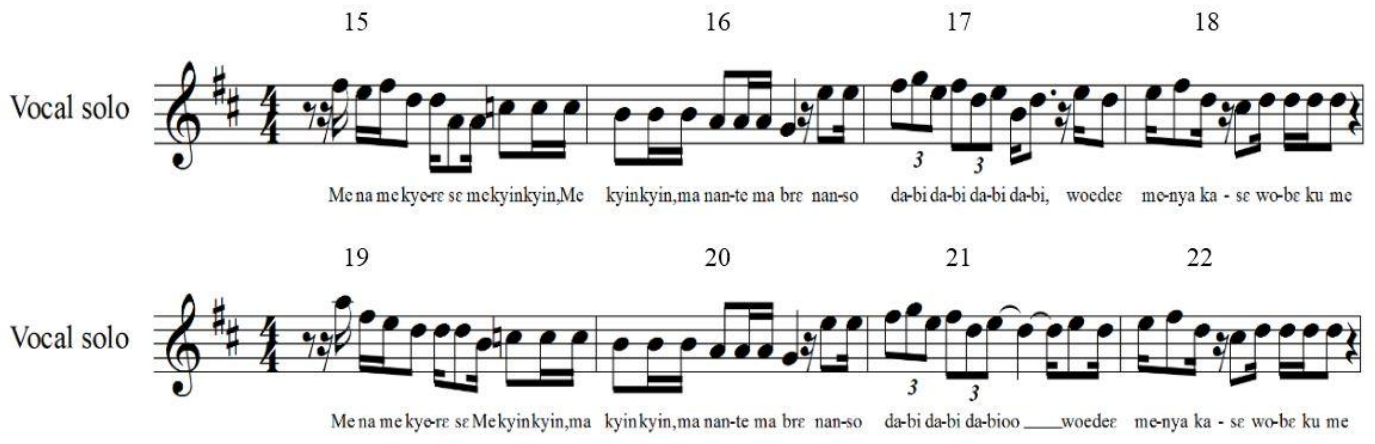

Figure 8: Melody Range

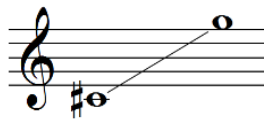

The melody ranges from C\#4-G5 as illustrated in figure 8 above. It is worth noting that for melodic variety and continuity of the song, the songwriter combines the use of ascending and descending leaps coupled with stepwise motion and note repeats.

\subsection{Arrangement of the Song}

The vocal melody of the song, as we have mentioned earlier, was composed by Kwadwo Donkoh while Stan Plange did the instrumental arrangement. Arranging according to (Corozine, 2002) is the art of giving an existing song musical variety, which may involve introducing new ideas such as introductions, pre-chorus, chorus, bridge, coda etc. Similarly, (Coffie, 2012) informs that arrangement is the relationship between the various instrumental sections and voice, and therefore, a musical style is determined by the arrangement. In this section, we discuss the arranging styles Stan Plange employs and how the various instrumental sections relate with the voice.

\subsection{Instrumental Resources}

Vocal

Winds/Brass/Horns

Keyboard Synthesizer

Strings (guitar and bass)

Percussion
Solo Voice

Alto Saxophone, Trumpet and Trombone

Electric Piano

Electric Guitar and Bass

Claves, Cowbell, Maracas, Congas and Drum Set 
Table 2: Structural Organisation of the Song

\begin{tabular}{|c|c|c|}
\hline Section & Time Marking & Description \\
\hline Introduction (intro) & 0:00-0:09 & $\begin{array}{l}\text { The introduction has been woven into the body of the song } \\
\text { without break nor change in tempo. The horns section } \\
\text { expresses the relatively short intro with accompaniment by } \\
\text { the various instruments. }\end{array}$ \\
\hline Vocal solo & $0: 10-01: 47$ & The vocal melody begins with instrumental accompaniment. \\
\hline Horns Interlude 1 & $01: 48-02: 08$ & $\begin{array}{l}\text { The horns section interlude employs a melodic idea } \\
\text { different from the melodic idea of the introduction. }\end{array}$ \\
\hline Guitar Interlude & $02: 09-02: 57$ & $\begin{array}{l}\text { The guitar improvises based on the chords progression of } \\
\text { the vocal solo. }\end{array}$ \\
\hline Horns Interlude 2 & $02: 58-03: 20$ & $\begin{array}{l}\text { The horns section repeats the melodic idea, however, only } \\
\text { trombones play. }\end{array}$ \\
\hline Vocal solo & 03:21-04:08 & The vocal melody repeats. \\
\hline Coda (outro) & 04:09-04:30 & $\begin{array}{l}\text { The melodic idea of the horns section interlude is expressed } \\
\text { gracefully as coda. }\end{array}$ \\
\hline
\end{tabular}

\subsection{Instrumental Structure}

\subsubsection{Horns Section}

This song can be treated as a unitary form. Considering the relative simplicity of the vocal melody, the arranger employs two different melody ideas in the horns to interact with the voice and also sustain the listener's interest. The first melody idea of the horns section occurs in the introduction, where the arranger employs note repeats, interlocking patterns, punches and quasi-hocketing as illustrated in figure 9 below.

Figure 9: Horns Intro

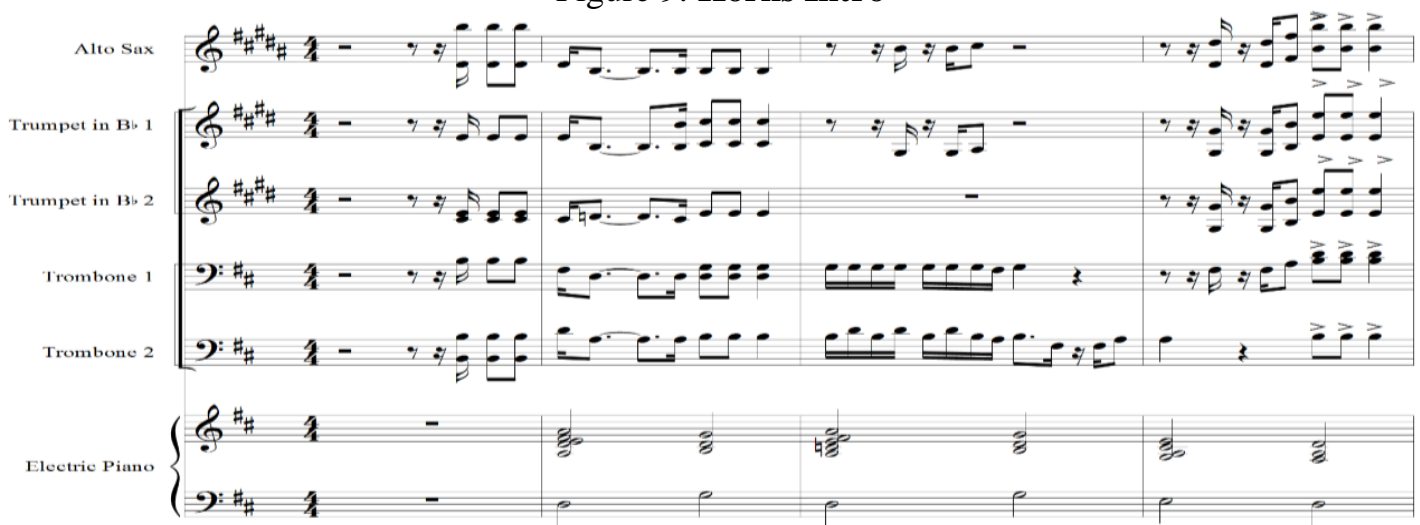

Referring to the illustration above,the introduction is quite short; however, to get the listener's attention, the arranger begins with a homophonic texture in bars 1-2 in the form of a statement, then followed by a quick polyphonic response in bar 3. Supported by chord V in the keyboard in bar 4 second beat, the dominant actively moves in the direction of the tonic to suggest a perfect cadence in the horns in homophony. The note repeats in the second half of bar 4, which is treated as a punch (accent) is emphasised, not only as goals of accents but also the vocal solo enter in bar 5 after the repeated note is reached. Notice that because of the quasi-hocketing nature of the horns introduction, the melody does not seem to remain in one part. The melody can be seen in the alto saxophone and trumpet with note repeats in bars 12 , the second trombone takes over in bar 3 with interlocking melody, which is quickly followed by the entire horns in bar 4. The trombones add the sixth note (B) in parallel thirds to the tonic (D) in the second half of bar 4 for decoration; this is a common practice in dance band highlife pitch organisation. Notice the harmonic parallelism and polarity, which is also a common practice in African traditional vocal music. The second melody idea of the horns section occurs in the interlude and coda, where the arranger employs sequential interlocking melodic pattern and note repeats as illustrated in figure 10 below. 
Figure 10: Horns Interlude 1

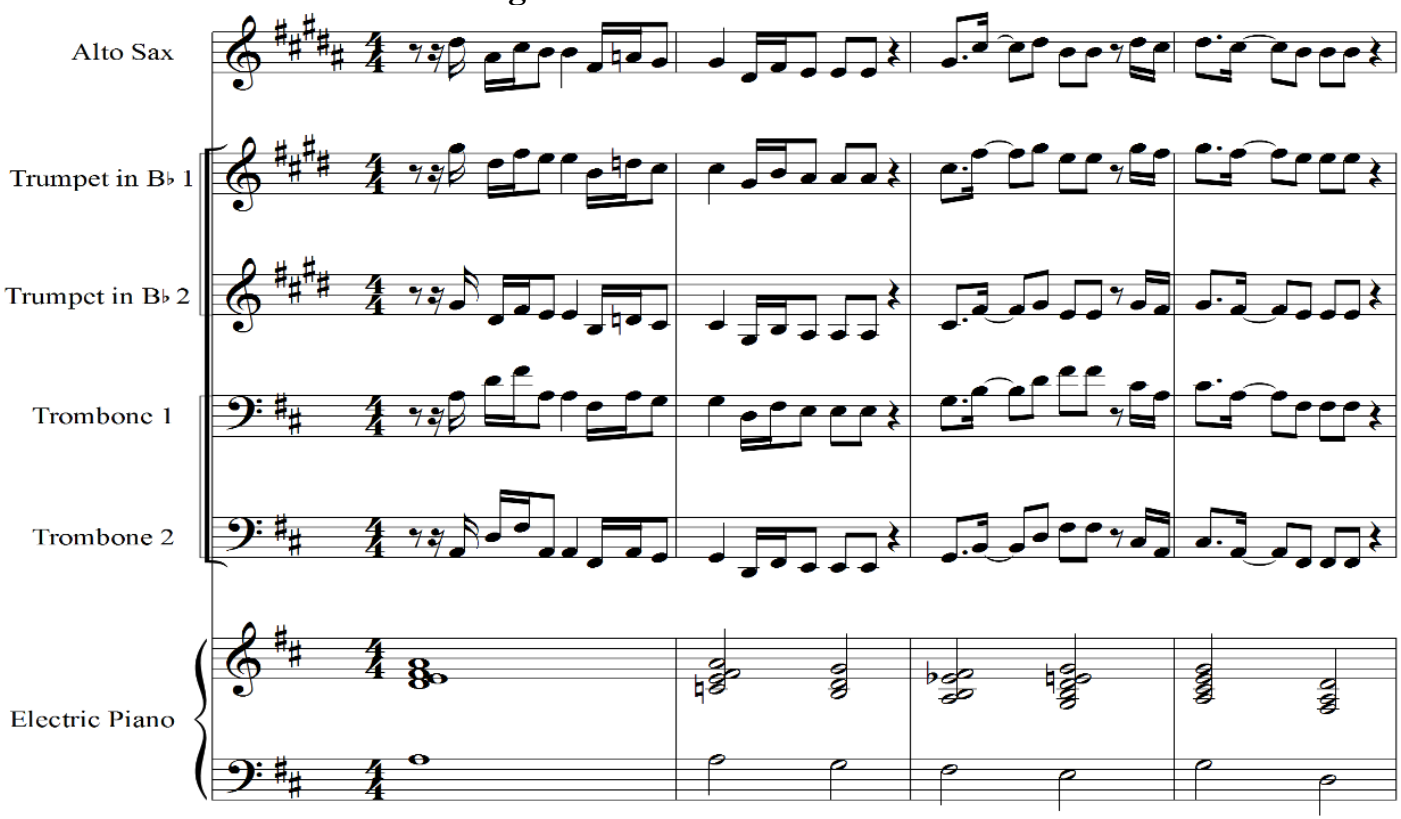

Referring to the illustration above, the arranger varies the horns texture with two-part harmony. The same melody is repeated for the second interlude for only the trombones; however, not without variation in the harmony. Notice the polarity in the trombone as illustrated in figure 11 below.

Figure 11: Horns Interlude 2

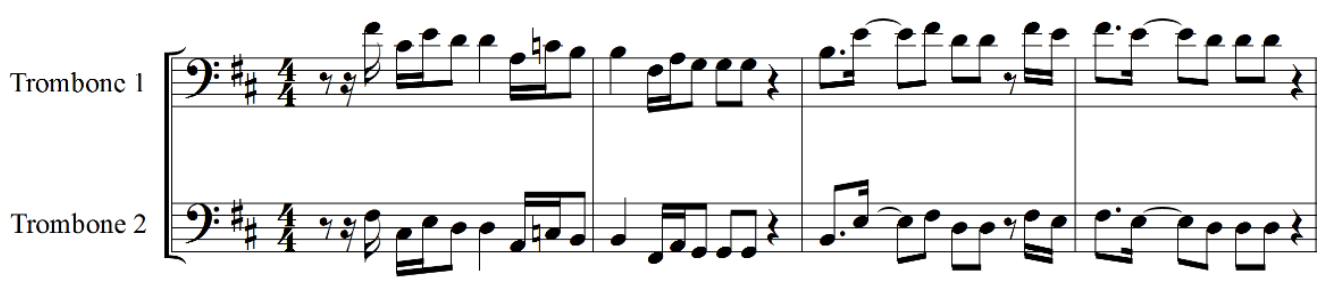

It is also worth noting that the arranger alternates the horns interlude with the vocal melody, and this is what (Coffie, 2012) refers to as double theme brass-vocal alternation arranging technique ${ }^{7}$ in dance band highlife music. The arranger, in order not to sound predictable, varies the harmony of the horns interlude by employing tertian harmony for the coda, which also brings finality to the song. See the illustration in figure 12 below.

${ }^{7}$ Also see (Coffie, 2018) 
Figure 12: Horns Coda

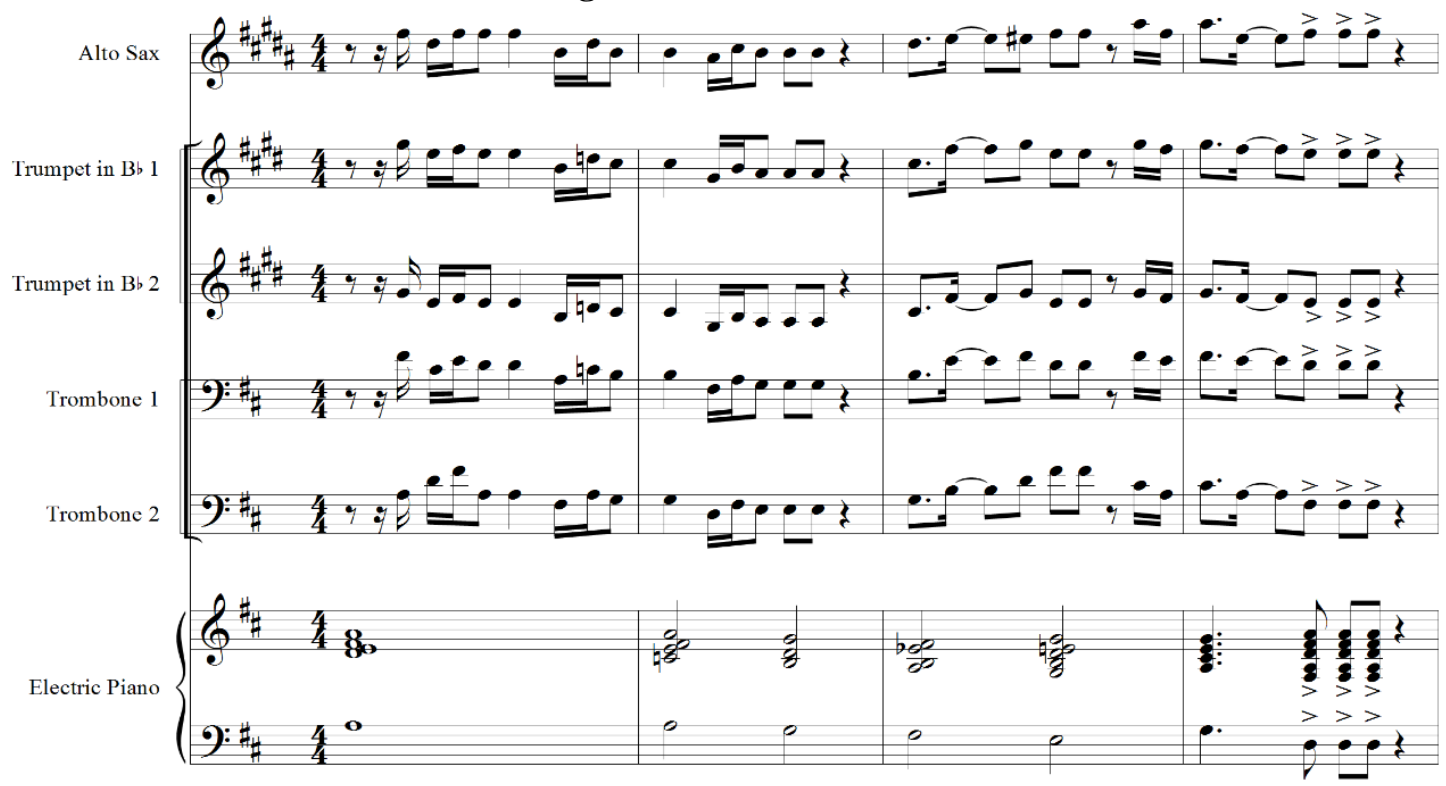

\subsubsection{Keyboard}

The keyboard makes use of block chords. Bar by bar examination of the keyboard accompaniment reveals the usage of primary, secondary and advanced chords, as shown in the table below.

Table 3: Keyboard Chord Structure

\begin{tabular}{|c|c|}
\hline Bar Number & Chord Structure \\
\hline 5 & D Maj. added 9 $^{\text {th }}-$ \\
\hline 6 & D $^{9}-$ G Maj. \\
\hline 7 & $\mathrm{~B}^{7}$ second inversion - E min. \\
\hline 8 & $\mathrm{~A}^{7}$ second inversion - D Maj. \\
\hline 9 & D Maj. added 9 $^{\text {th }}-$ \\
\hline 10 & $\mathrm{D}^{9}-$ G Maj. \\
\hline 11 & $\mathrm{~B}^{7}$ second inversion - E min. \\
\hline 12 & $\mathrm{~A}^{7}$ second inversion - D Maj. \\
\hline 13 & D Maj. added $9^{\text {th }}$ second inversion - \\
\hline 14 & D Maj. added $9^{\text {th }}$ second inversion - \\
\hline 15 & D Maj. added $9^{\text {th }}$ second inversion \\
\hline 16 & D half dim. second inversion - G Maj. \\
\hline 17 & $\mathrm{~B}^{7}$ second inversion - E min. \\
\hline 18 & $\mathrm{~A}^{7}$ third inversion - D Maj. \\
\hline
\end{tabular}

Note that the chords structure illustrated in the table above is what underlies the entire vocal solo.

\subsubsection{Guitar}

The guitar employs the mainline, one of the indigenous Ghanaian highlife guitar styles. This guitar style combines the West African two-finger guitar plucking technique and block chords. This technique of playing the guitar is a transfer of technique of plucking indigenous harp-lutes such as the Akan seperewa, Sene-Gambian kora, the Liberian luu, and Yoruba molo and onto the Spanish guitar (Collins, 1994). The rhythms found in the guitar pattern are short, repetitive and full of syncopations ${ }^{8}$ as illustrated in figure 13 below.

\footnotetext{
${ }^{8}$ Also see (Collins, 2006) and (Yamson, 2016)
} 


\section{Figure 13: Guitar and Bass pattern}

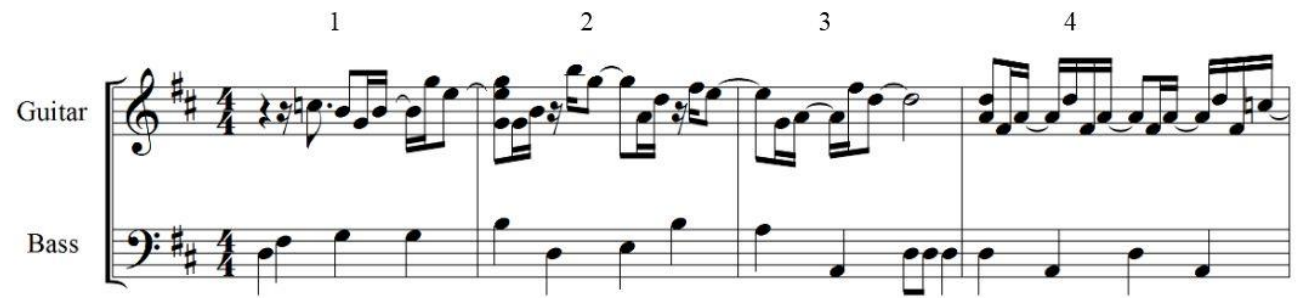

\subsubsection{Bass Guitar}

The bass begins in bar 1 with a walking bass pattern. Syncopation is usually absent in this pattern since the regular pulse of the rhythm is sounded. As illustrated in figure 13 above, the bass provides the chord scheme for the horns introduction. Note that the walking bass is the fundamental bass pattern of dance band highlife music.

Figure 14: Percussion

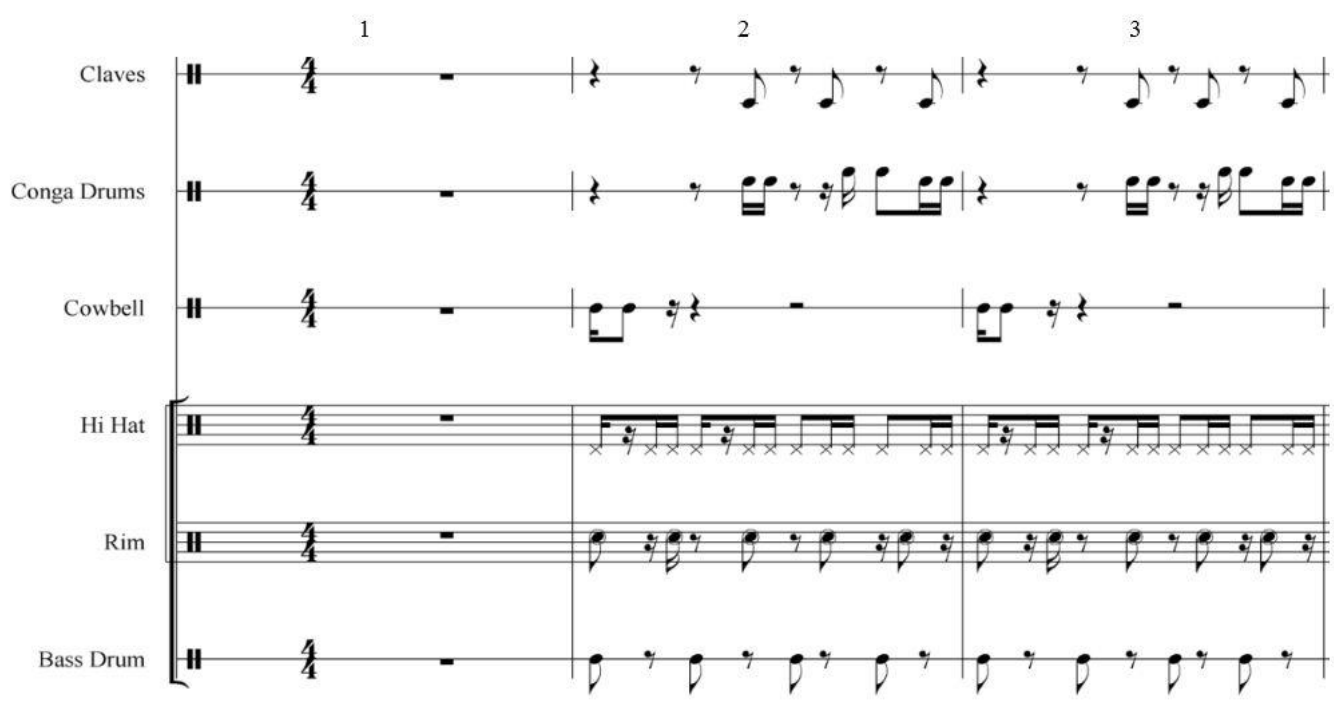

An examination of the rhythmic structure of the percussion as illustrated above reveals an interesting interaction between the various rhythmic instruments. For example, the bass drum begins in bar 2 in a common time ${ }_{4}^{4}$ metre and sounds the regular pulse, which is the downbeat. The rim plays offbeat to the bass drum; it only goes together with the bass drum at the beginning of each bar. The hi-hat fills the gaps within the rim and the bass drum, and also holds them together. The claves, as usual, provides the timeline for the song by playing an upbeat response to the bass drum. The claves, for example in bar 2 second and third beat, emphasises the sound of the rim. Note that the cowbell is used as a complement to the clave, while the conga drum is used for embellishment. The ostinato pattern found in bar 2 is what underlies the entire song.

\section{Conclusion}

It is quite obvious that Kwadwo Donkoh, an average organist remarkably composed several vocal melodies for bands such as Tempos, Uhuru, Ramblers and Ogyatana Bands based on the level of his musical training, which was primarily through self-tutoring and imitation. Kwadwo did not have much knowledge in the theory of music but managed to manipulate compositional devices such as sequential interlocking patterns, repetitions, variations and transposition to come out with such a novel song; which is worth commending. Kwadwo's sense of lyricism was an influence from the guitar band highlife tradition, where composers pay particular attention to text and melody. Stan Plange, by contrast, was a fantastic guitarist and had his training in big band music arranging through a correspondence course in Berklee College of Music. His knowledge in big band music arranging made him arrange for bands such as Stargazers, Ambassadors Down Beats, Broadway, Uhuru, Black Star Line, and Ghana and Nigeria Broadcasting Bands. In the song, Wobe kume, Stan employed double theme brass and vocal alternation arranging technique as observed by (Coffie, 2012). The manipulation of musical elements such as harmonic parallelism, primary, secondary and advanced chords, sequential interlocking patterns, counterpoint and chromaticism in arranging the song is evidence of Stan's quality in Ghanaian dance band highlife arranging. 
Considering the instrumental arrangement in relation to the relative simplicity of the vocal melody of Wobe kume, we can conclude that the song is a contribution to music theory; and therefore, recommend the use of Ghanaian dance band highlife songs for the teaching of composition and big band arranging techniques, and musical form and analysis in music institutions.

\section{References}

Aduonum, K. (1983). Ghanaian Musicians, Past and Present: A handbook for Schools and Colleges. Unpublished manuscript.

Aidoo, S. (2014). Saxophone solos in Ghanaian Highlife Music: An analytical study of Tempos and Rumblers International Bands (Unpublished M.Phil Thesis). University of Ghana.

Ampomah, K. (2013). Indigenous origins of Ghanaian highlife music. Journal of African Arts and Culture, 1(1), 7181.

Amuah, J. A., Sunu Doe, E., Fiagbedzi, E. E. K., \& Amenyo, C. A. (2014). The concept of chromaticism in Ghanaian highlife music: A study of Kwadwo Donkoh's wobe kume (you will kill me). American Journal of Social Sciences, Arts and Literature, 1(1), 1-8.

Bender, W. (1991). Sweet Mother. London: Chicago Press Ltd.

Coffie, M. M. (2012). Dance band highlife: Analytical study of Ebo Taylor, Stan Plange and Kwadwo Donkoh. (Unpublished M. Phil Thesis.). University of Ghana.

Coffie, M. M. (2018). Bigshots Band's Too Ke Adun: A modern Ghanaian dance band highlife music. Journal of African Arts \& Culture, 2(2), 33-51.

Collins, J. (1985). Music Makers of West Africa. Washington DC: Three Continent Press.

Collins, J. (1986). E.T. Mensah: King of Highlife. London: Off the Record Press.

Collins, J. (1994). Highlife Time. Accra: Anansesem Press.

Collins, J. (2004). King of the Black Beats. Unpublished Manuscript.

Collins, J. (2006). African guitarism: One hundred years of West African highlife. Legon Journal of the Humanities, 17, 173-196.

Collins, J. (2016). Highlife Giants: West African Dance Band Pioneers. Abuja: Cassava Republic Press.

Collins, J. (2018). Highlife Time 3. Dakpabli \& Associates.

Coplan, D. B. (1978). Go to my town, Cape Coast!: The social history of Ghanaian highlife. In B. Nettl (Ed.), Eight Urban Musical Cultures (pp. 96-114). Urbana.

Corozine, V. (2002). Arranging music for the real world: Classical and commercial aspects. Pacific MO: Mel Bay.

Kudonu, K. (2012). New Trends in Ghanaian Popular Music: A case study of Local Dimension Band (Unpublished M. Phil Thesis). University of Ghana.

Marfo, P. (2016). The appropriation of local instruments into Ghanaian Highlife music: A study of Rumblers Dance Band (Unpublished M.Phil Thesis). University of Ghana.

Smith, E. M. (1962). Popular Music in West Africa. African Music, 3 (1), 11-17.

Webb, G. (2011). The Wulomei Ga Folk Group: A Contribution Towards Urban Ethnomusicology (Unpublished PhD Dissertation). University of Ghana, Accra.

Yamson, F. A. (2016). Ghanaian guitar highlife music styles (Unpublish M. Phil Thesis). University of Education, Winneba. 